\title{
PQRST in Teaching Reading Comprehension for the First Semester Student of Nursing Study Program STIK Siti Khadijah Palembang
}

\author{
Nyayu Yayu Suryani ${ }^{1}$, Surya Darma $^{2}$, Arif Pamuji ${ }^{3}$ \\ ${ }^{1}$ STIK Siti Khadijah Palembang, South Sumatera Indonesia \\ email: Nyayuyayusuryani@gmail.com \\ ${ }^{2}$ STIK Siti Khadijah Palembang, South Sumatera Indonesia \\ email: Suryakiki9@gmail.com \\ ${ }^{3}$ STIK Bina Husada Palembang, South Sumatera Indonesia \\ email: Arief_black85@gmail.com
}

\begin{abstract}
The objectives of this study were to find out: (1) the significant improvement on the first semester students' reading comprehension before and after being taught using PQRST technique at STIK Siti Khadijah Palembang, South Sumatera, Indonesia; and (2) the significant difference on students' reading comprehension between the students who were taught by using PQRST technique and those who were not. The population of this research was all the first semester students of STIK Siti Khadijah Palembang which consist of 32 students in academic year 2019/2020. The sample of this research was taken by using total sampling. Thus, the total number of the sample was 32 students. The sample was the first semester students at Nursing Study Program (experimental group) which consist of 32 students and the third semester students at D.III Nursing Study Program (control group) which consist of 32 students. The test was given twice to both experimental and control group. True experimental design was used to analyzed the data. To verify the hypotheses, the data used post-test design to analyzed by using paired sample t-test and independent sample t-test was 0.005 which was lower than 0.05 .The result of this research showed that Reading Comprehension by using PQRST technique gave significant improvement on the students' reading comprehension and gave significant difference between students' who were taught by PQRST technique and those who were not.
\end{abstract}

Keywords: Reading comprehension, PQRST, Student of STIK Siti Khadijah 


\section{INTRODUCTION}

Reading is an important skill and a key success for a student to learn. It is one of the four main skills of language learning. It is a process of getting comprehension of written text. It is a complex process of decoding symbols which purposes to gain understanding. Through reading a students can increase vocabulary, improve memory and enhance knowledge. According to Brown (1998), reading is a process to understand a written text which means extracting the acquired. Reading comprehension is the process of simultaneously extracting and constructing meaning through interaction and involvement with written language (Snow, 2002, p.11). When reading, the readers should be able to manage every part of the text, because it is easy to comprehend the ideas conveyed on the text when the readers are able to analyze the organization of the text. According to Doyle (2004), comprehension is a progressive skill in attaching meaning beginning at the same level and proceeding to attaching meaning to an entire reading selection. In teaching reading, most of teachers emphasize on explanation and definition of text, then they ask students to do the exercises by answering questions based on the text given. There is a lack of guidance to comprehend the text, while the idea of reading comprehension is getting the idea of the reading text. Therefore, the crucial thing of teaching reading is leading the students to engage their mind in the text. Then, by comprehending the text well the students can get new information. In other words, they learn new knowledge that is studying.

There are some strategies of teaching reading which are interesting and can improve students' reading skills, but not all strategies can fit with the text and students' needs. It means the teacher has a great responsibility in considering the strategy that they want to apply in order to improve her students' reading comprehension.

One of the strategies may be appropriate is $\mathrm{PQRST}$ strategy. $\mathrm{PQRST}$ (Preview, Question, Read, Summarize, and Test) is one of strategies that can lead the students reading comprehension (Thomas \& Robinson,1982). According to Sulistyo, (2011, p. 94-95), reference conceptually the PQRST strategy is one the teaching strategies which comprise of five stages/schemes: Preview, Question, Read, Summarize, and Test. It provides a step-by step guidance to students before, during, and after their reading process which is essential for their comprehension. Each stage gives benefits to students in facilitating their learning. As an instructional strategy, PQRST strategy helps students to cope their problem in reading comprehension by using five steps. They are previewing, questioning, reading summarizing, and testing. Each step of PQRST strategy improves the teaching and learning process which is also aimed to improve the students' reading comprehension. Briefly, PQRST strategy may able to make students become active in reading process, make them focus on the text, attract their motivation have a long- 
term memory in comprehending the text and increase their score on the test.

Traditional English teaching strategy is not so effective to improve the students' reading comprehension. Due to the weakness of traditional technique in reading comprehension, the writer wishes to try to applying PQRST in teaching reading comprehension. The writer assumes that strategy will help students to improve their reading comprehension. Because of that, the writer is interested in conducting a research entitled "PQRST in Teaching Reading Comprehension for the First Semester Student of Nursing Study Program STIK Siti Khadijah Palembang”.

\section{METHOD}

The experiment is used in this research. There are forms of experiment design. In this research the writer used True Experimental Design. There are two forms of true experiment, it is Posttest only control design and pretest group design. In this research the writer used posttest only control design. In this design the writer implements a treatment on the experimental class but does not implement it on the control class. The treatment is the independent variable: PQRST method in the experimental group. and Traditional Method in the control group.

This investigation was conducted to the first semester students of STIK Siti Khadijah Palembang in Academic Year 2019/2020. The research conducted from October to November 2019.
There are two kinds of variables, Independent and dependent variable. Independent variable $(\mathrm{X})$ : The implementation of PQRST and Conventional Method. Dependent variable (Y): Students' ability in reading comprehension text.

The design of this research used true experimental design posttest only control design by using randomized sampling which was giving posttest. In this design there are two groups each of which was chosen at random (R). The first group was treated $(\mathrm{X})$ and the other group was not give treatment. The design of experimental research can be seen as follow:

Experiment: R X1 O1

$$
\text { Control : R X2 O2 }
$$

Where:

$\mathrm{R}$ : Sample in randomized

X1 : PQRST method

X2 : Conventional Method

O1 : Post-test for PQRST Method

O2 : Post-test for Conventional Method

The population of this research was students of STIK Siti Khadijah Palembang S1 Nursing Study Program in Academic year 2019/2020 which is consist of 32 students.

The sample of this research was a random sampling method used to select the class. Then, the selected classes are grouped into two categories. One group was used as control class taught using conventional 
method, and other group is treated as experimental class taught using PQRST. In choosing sample of the research, the writer got the first semester as the experimental group and the third semester as the control group. The number sample in experimental group was 32 students and 32 students in control group.

In this research, the data are resulted from the test of students' reading comprehension in English. In this research, the writer used posttest to find out the students' achievement in reading comprehension after implementing two methods in order to measure students' competence. The writer used objective test. It was multiple-choice test. The test consist of 40 questions with 4 alternative choices a, b, c or d for 90 minutes. Posttest was given after two classes were given treatment on October,2019 for the experimental class. and November, 2019 for control class. The purpose of this test was to know which one who got higher score between this experimental class and control class.

Burns (1999, p. 80) says that observation is taking reguler conscious to notice of classroom act and occurence which are particularly relevant to the issues or topics being investigated. In this research, observation was done by the writer. Observation is a way of finding out more about the students' responses. Students' behaviors and activities were observed by during the English classes. The observation was focusing on the development of students' reading comprehension by using PQRSR in experimental class and Conventional method in control class.

This section discusses the indicators of instruments and test instrument. The reading comprehension test for posttest consisting of 40 items in the form of multiple choice. The instrument taken from books and internet. The reading test includes the seven aspect of comprehension as suggested by Cooper at al (1988, p. 3248) details, main idea, reference, sequence, cause and effect, inference, and meaning of words and terminology. The specification of the reading comprehension test in table 1 below :

Table 1. Specification of Reading Comprehension Test

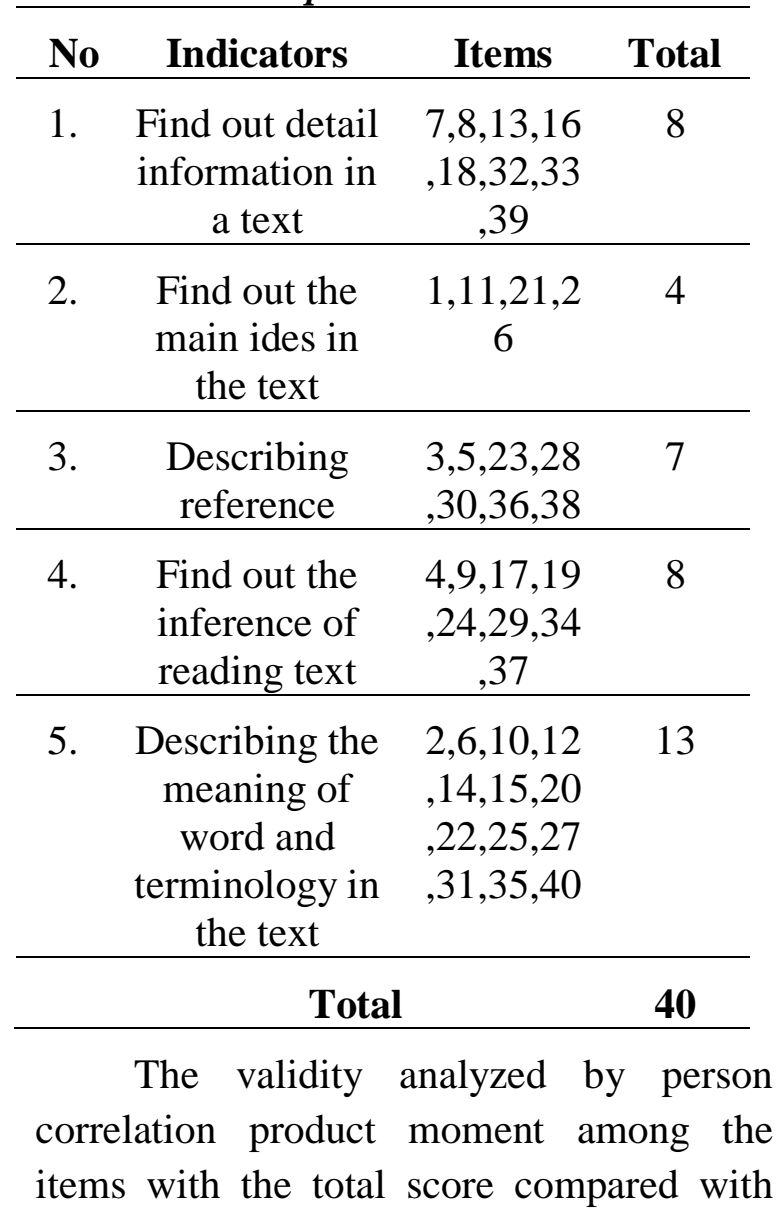


table correlation. If pearson correlation product moment scores are higher than table correlation scores so the item of the questions are valid.

For the reliability, the writer use Alpha Cronbach Using SPSS. According to Wallen and Fraenkel (1990, p. 99), reliability should be at least 0.70 and preferbly higher. The reliability obtained was 0,995

In analyzing the data, test was analyzed by the writer. The data then were checked and scored manually by using particular system. There were 40 items in reading comprehension test. Each correct item was scored by 2.5 , the score for wrong answer was 0 . In the case the students who did not give the answer would also get 0 . The obtain data then were analyzed by using SPSS version 21. Descriptive statistic including means and standard deviation were given to support the research. The $t$ test was used on SPSS program to compare the data in order to determine whether there were significant means difference between experiment and control groups after the treatment.

\section{FINDINGS AND DISCUSSION}

Teaching reading was done by the writer to find out the students' ability in reading comprehension through PQRST to the subject under study, the first semester students of STIK Siti Khadijah Palembang S1 Nursing Study Program in Academic year 2019/2020. The writer held this research by teaching reading process that was done at two classes those are the first semester students of S1 Nursing Study Program as experiment class and the first semester students of D.III Nursing Study Program as control class at STIK Siti Khadijah Palembang.

After teaching reading process that was done, here are the result of reading comprehension. the description includes the mean, the mode, the median, the standard deviation and frequency distribution followed by histogram and polygon. The writer got the data from post-test, which was given after the lesson finished.

Based on the group analyzed, the descriptions of the data can be divided into two groups, they are as follows:

1. The post-test data of reading comprehension the students of the group taught by PQRST (Post-test experiment)

Descriptive analysis of the post-test data from experiment class shows that the score is 75 up to 85 . The mean is 79.94 , The standar deviation is 3.037 , the mode is 78 , the median is 79.50. The descriptive analysis of the data post-test for control class in table 2 and Histogram is presented in figure 1 below: 
normal, the result of normality test could be seen in table 3 below:

Table 3. The Test of Normality

Test of Normality

\begin{tabular}{cccccccc}
\hline & \multicolumn{4}{c}{$\begin{array}{c}\text { Kolmogorov- } \\
\text { Smirnov }\end{array}$} & \multicolumn{4}{c}{ Shapiro-Wilk } \\
\cline { 2 - 7 } & tatistic & f & ig. & tatistic & f & ig. \\
\hline ost_eks & 145 & 2 & 087 & 938 & 2 & 065 \\
\hline ost_ctrl & 134 & 2 & 157 & 978 & 2 & 735 \\
\hline
\end{tabular}

a. Lilliefors Significance Correction

The result of normality test in Kolmogrov-Smirnov shows the significance value of PQRST which was 0.087. Since the significance value of PQRST was higher than 0.05 , it could be called that the distribution sample of PQRST was normal. Then, it could also be seen that the significant value of Conventional in Kolmogorov-Smirnov was 0.157. This significant value was also higher than 0.05 . It means that the distribution sample of conventional strategy was also normal. Furthermore, the result of normality test in Shapiro-Wilk show the significant value of PQRST strategy was 0.065 . This significant value was higher than 0.05 . It could be called that the distribution sample of PQRST in Shapiro-Wilk was normal. In addition, teaching reading by using conventional has a significant value 0.010 which was also higher than 0.735 . It means that the distribution sample of conventional was also normal.

2. Statistical Analysis on Measuring Homogenity of the Data
In estimating whether the data were homogenous, the writer used the test of homogenity of variance by using SPSS program as could be seen in Table 4 below:

Table 4. The homogeneity of the Data ANOVA

\begin{tabular}{|c|c|c|c|c|c|}
\hline & $\begin{array}{l}\text { Sum } \\
\text { of } \\
\text { Square } \\
\text { S }\end{array}$ & df & $\begin{array}{l}\text { Mean } \\
\text { Square }\end{array}$ & $\mathrm{F}$ & Sig. \\
\hline $\begin{array}{l}\text { Between } \\
\text { Groups }\end{array}$ & $\begin{array}{l}113.61 \\
3\end{array}$ & 10 & 11.361 & 1.385 & 5.253 \\
\hline $\begin{array}{l}\text { Within } \\
\text { Groups }\end{array}$ & $\begin{array}{l}172.26 \\
2\end{array}$ & 21 & 8.203 & & \\
\hline$\overline{\text { Total }}$ & $\begin{array}{l}285.87 \\
5\end{array}$ & & & & \\
\hline
\end{tabular}

The result of homogenity of variance testing indicated that the significant of $\mathrm{p}$ value 0.05 . As it could be seen in Table 7 , the significant value was 0.253 . It means that the data were homogenity in variance. It could be interpreted that the data taken from PQRST in homogenity variance.

Hypothesis test can be done after the result of normality and homogenity test are fulfilled. The test was done by using independent sample $\mathrm{t}$ test. Ho is rejected if $\mathrm{t}$ $>\mathrm{t}$ table meaning that there were differences. The variable was described in table 5 below: 
Table 5. Paired Samples Test

\section{Paired Samples Test}

Paired Differences

\begin{tabular}{|c|c|c|c|c|}
\hline \multicolumn{3}{|c|}{ Paired Differences } & \multirow[b]{2}{*}{ df } & \multirow[b]{2}{*}{$\begin{array}{l}\text { Sig. } \\
\text { tailed) }\end{array}$} \\
\hline Std. & $\begin{array}{l}\text { Std. } \\
\text { Error }\end{array}$ & $\begin{array}{l}\text { 95\% Confidence Interval of the } \\
\text { Difference }\end{array}$ & & \\
\hline Mean Deviatior & Mean & Upper & & \\
\hline
\end{tabular}

\begin{tabular}{l|l|l|}
\hline $\begin{array}{l}\text { Pair post_2.844 } \\
\text { eks }\end{array}$ & 3.638 & .643 \\
$\begin{array}{l}\text { post__ } \\
\text { ctrl }\end{array}$ & & \\
\hline
\end{tabular}

To determine whether there is a main effect for independent variable toward dependent variable, it is necessary to check the significance value of each variable. If the value is less than 0.05 , there is a significance difference for each variable and if the value is more than 0.05 there is no significance difference for each variable. From the sig. column of table 5, it could be seen that the significance value was 0.000 . It means that there was significance difference in students' reading comprehension between the students' taught using PQRST and Conventional method.

\section{CONCLUSION}

Based on the data analysis, the researcher draws some conclusion as follows:

1. The implementation of PQRST to teach reading at the first semester students of STIK Siti Khadijah Palembang Nursing Study Program. Each meeting id divided into four stages : Preview, the students to identify the title, picture, figure, number, italic words in the text. Question, the teacher develops questions to which the students want to find answers. Read, the teacher gives the text to the students. Summarize, the teacher may ask the students to summarize by recalling the important ideas from the section reader just read. Test, the teacher tries to measure the understanding of the students by giving a test.

2. There is significant difference of the effects on the students' reading comprehension between those who were taught using PQRST and those who were taught using Conventional method. To determine whether there is a main effect for independent variable toward dependent variable, it is necessary to check the significance value of each variable. If the value is less than 0.05 , there is a significance difference for each variable and if the value is more than 0.05 there is no significance difference for each variable. From the sig. column it could be seen that the significance value was 0.000 . It means that there was significance difference in students' reading comprehension between 
the students' taught using PQRST and Conventional method.

\section{REFERENCES}

Burns, P. C, Betty, D. R, \& Elinor, P, R. 1984. Teaching Reading Today's Elementary School, Boston, MA: Houghton Mifflin. Co.

Brown. H. D. 1998. Teaching by principles: an interactive approach to language pedagogy. English cliffs, New Jersey: Prentice Hall Regents. Asian Journal of English Language Teaching, 8(1), 117123.

www.cuhk.edu.hk/ajelt/vol8/rev1.htm (Accessed on: December 6th, 2016).

Cooper, J.D., E.W. Warneke, and D.A. Shipman. 1988. The What and How Reading Instruction. Columbus, $\mathrm{OH}$ : Merril Publishing Company.

Doyle, B.S. 2004. Main Idea and Topic Sentence. London: Ward Lock Educational.

Everatt. John. Barbara Mc Corquodale and Julie Smith. 1999 " Association between Reading Aility and Visual Processes" John Everatt. Reading and Dyslexia Visual and Attentional Processes. London: Routledge 1-31.

Fraenkel, Jack and Norman E Wallen. 1990. How to Design and Evaluate Research in Education. San Fransisco: State University Press.

Snow, C. 2002. RAND, Reading Study Group. Reading for Understanding: toward an $R \& D$ Program in Reading Comprehension. Santa Monica: Rand Corporation.
Sulistyo, G.H. 2011. Reading for meaning. Malang: Pustaka Kaiswaran.

Insani,2013. The Effect of Using PQRST Method on Reading Comprehension Ability of the Seventh Grade Students of SMP Diponegoro Depok. A Thesis.Yogyakarta State University

Thomas, E.L., and Robinson H.A.1982. Improving Reading in Every Class. Boston: Allyn \& Bacon Press. https://www.amazon.com/ (Accessed on: December 4th, 2016) 